\title{
STUDIES ON THE EXCRETION PATTERN OF PORPHYRINS AND ITS USE AS A TOOL FOR DIAGNOSING BOTH SYMPTOMATIC AND ASYMPTOMATIC CASES OF PORPHYRIA CUTANEA TARDA
}

\author{
Pedro H. Magnin, Eva A. Wider de Xifra, Mario Lenczner, \\ ana María Sitlla and Alcika M. del C. Batlle \\ Centro de Investigaciones sobre Porfirinas y Porfirias, CIPYP, Facultad de Ciencias Exactas y Naturales, \\ Universidad de Buenos Aires y Consejo Nacional de Investigaciones Científicas y Técnicas, \\ CONICET, Ciudad Universitaria, Pabellón II, 4to Piso, Nún̄ez, 1428 Buenos Aires and \\ Servicio de la Cátedra de Dermatologia, Facultad de Medicina, Universidad de Buenos Aires, \\ Hospital Ramos Mejia, Urquiza 609, 1221 Buenos Aires, Argentina
}

\begin{abstract}
A family investigation was performed in eleven cases of Porphyria Cutanea Tarda (PCT).
2. By using clinical findings, quantitative measurements and thin layer chromatography (TLC) of urinary porphyrins, overt and subclinical PCT patients have been identified.

3. In the overt type, skin manifestations are present, excretion of urinary porphyrins is increased and the TLC pattern of porphyrins in urine is characteristic for PCT.

4. In the subclinical type, patients have no clinical symptoms, excretion of porphyrins in urine might be normal or enhanced and TLC pattern of urinary porphyrins is typical for PCT.

5. By applying these criteria a clear distinction between hereditary and non-hereditary PCT was possible.

6. Among the 11 families studied, in four families where PCT was hereditary, four members have the overt type and ten relatives the subclinical type.

7. In seven families where PCT was non-hereditary only the propositus has overt PCT and not a single relative showed any clinical or biochemical abnormality.
\end{abstract}

\section{INTRODUCTION}

Porphyria Cutanea Tarda (PCT) has been regarded as acquired or non-hereditary because of its onset in middle or late life. The most important causative factor is usually considered to be abuse of alcohol and it is also associated with the use of other factors such as estrogens, halogenated hydrocarbons and iron. However it has long been suspected that PCT can be an inheritable disease (Waldenström \& HaegerAronsen, 1963; Perrot \& Thivolet, 1970; McEwin, 1973; Dehlin et al., 1973; Prato et al., 1974; Topi \& D'Alessandro, 1977).

Specific enzymic defects have been assigned to each porphyria, among them PCT is characterized by a deficiency in the activity of Uroporphyrinogen decarboxylase and recently a reduction of this enzyme has been found in hepatic tissue and erythrocytes of patients and some of their clinically asymptomatic relatives (Kushner et al., 1976; Benedetto et al., 1978; Felsher et al., 1978; Elder et al., 1978; Verneuil et al., 1978). This enzymic defect appears to be inherited as an autosomal dominant trait, with a low penetration; however, although measurements of erythrocyte UPG-Dcase levels in PCT patients and their relatives might allow a clear distinction between the acquired and inherited types of PCT, the technique is not always suitable for routine work; moreover, some of these studies have produced contradictory results (Blekkenhorst et al., 1976).

It has been already reported that a systematic study of the urinary and fecal porphyrins using simple screening methods, such as thin layer chromatography (TLC) is a very useful technique for per- forming family studies, which can show any minor abnormalities in both clinically symptomatic and asymptomatic PCT patients (Doss et al., 1971; With, 1975, 1976; Piñol-Aguadé et al., 1975; Wider de Xifra et al., 1979; Batlle et al., 1979).

It is also clear that the hereditary of a case of Porphyria can only be clucidated by carrying out a study of both the patient and as many blood relatives as possible.

This report describes eleven cases of PCT, where a family investigation was performed with good collaboration from all relatives, to obtain further information about the existence of two forms of PCT: acquired and hereditary. The biochemical studies include analysis of the urine, blood and feces for porphyrins and for precursors, when available fine needle liver biopsy for porphyrins, and study of the TLC pattern of urinary porphyrins.

\section{MATERIALS AND METHODS}

Urinary, fecal and blood porphyrin determinations were performed by the solvent fractionation method described by Rimington (1971). The porphyrin methyl esters were analyzed qualitative and quantitatively by TLC (With, 1975; Wider de Xifra et al., 1979). ALA and PBG were assayed in urine according to Mauzerall \& Granick (1956). Porphyrins were investigated in liver biopsy smears by fluorescence microscopy and by solvent extraction, esterification and TLC.

\section{RESLLTS AND DISCUSSION}

To establish a diagnosis of PCT the following criteria were used: (i) the presence of the clinical syn- 
Table 1. Clinical and laboratory data of four families with porphyria cutanea tarda

\begin{tabular}{|c|c|c|c|c|c|c|c|c|}
\hline Family & Case & Sex & $\begin{array}{c}\text { Age } \\
\text { (years) }\end{array}$ & $\begin{array}{c}\text { Clinical } \\
\text { syndrome }\end{array}$ & $\begin{array}{c}\text { Liver } \\
\text { biopsy }\end{array}$ & $\begin{array}{l}\text { Urine } \\
\text { Porphyrins } \\
(\mathrm{g} / 24 \mathrm{hr})\end{array}$ & TLC & $\begin{array}{l}\text { lype of } \\
\text { PCT }\end{array}$ \\
\hline $\mathrm{CM}$ & $\begin{array}{l}\text { IIb } \\
\text { IIc } \\
\text { IId } \\
\text { IIIb } \\
\text { IIIc (pr.)* } \\
\text { IIId } \\
\text { IVa } \\
\text { IVb } \\
\text { IVc }\end{array}$ & $\begin{array}{c}\mathrm{F} \\
\mathrm{M} \\
\mathrm{M} \\
\mathrm{M} \\
\mathrm{M} \\
\mathrm{F} \\
\mathrm{M} \\
\mathrm{M} \\
\mathrm{F}\end{array}$ & $\begin{array}{r}47 \\
45 \\
48 \\
21 \\
29 \\
29 \\
3 \\
4 \\
6\end{array}$ & $\begin{array}{l}\text { No } \\
\text { No } \\
\text { No } \\
\text { No } \\
\text { Yes } \\
\text { No } \\
\text { No } \\
\text { No } \\
\text { No }\end{array}$ & + & $\begin{array}{r}705 \\
154 \\
415 \\
50 \\
1165 \\
20 \\
10 \\
16 \\
934\end{array}$ & $\begin{array}{l}\text { Abn } \dagger \\
\text { Abn } \\
\text { Abn } \\
N_{\ddagger}^{+} \\
\text {Abn } \\
N \\
N \\
N \\
\text { Abn }\end{array}$ & $\begin{array}{c}\text { Subclinical } \\
\text { Subclinical } \\
\text { Subclinical } \\
- \\
\text { Overt } \\
- \\
- \\
\text { Subclinical }\end{array}$ \\
\hline $\mathrm{CJ}$ & $\begin{array}{l}\text { IIa } \\
\text { IIb } \\
\text { IIc (pr.) } \\
\text { IIIa } \\
\text { IIIb }\end{array}$ & $\begin{array}{c}\mathbf{F} \\
\mathbf{F} \\
\mathbf{M} \\
\mathbf{F} \\
\mathbf{F}\end{array}$ & $\begin{array}{l}64 \\
66 \\
52 \\
18 \\
24\end{array}$ & $\begin{array}{l}\text { No } \\
\text { No } \\
\text { Yes } \\
\text { No } \\
\text { No }\end{array}$ & + & $\begin{array}{r}16 \\
23 \\
1633 \\
36 \\
18\end{array}$ & $\begin{array}{c}\text { Abn } \\
\text { Abn } \\
\text { Abn } \\
N \\
N\end{array}$ & $\begin{array}{c}\text { Subclinical } \\
\text { Subclinical } \\
\text { Overt } \\
- \\
-\end{array}$ \\
\hline FB & $\begin{array}{l}\text { Ia (pr.) } \\
\text { IIb } \\
\text { IIIa } \\
\text { IIIb }\end{array}$ & $\begin{array}{l}M \\
F \\
F \\
F\end{array}$ & $\begin{array}{l}70 \\
42 \\
10 \\
16\end{array}$ & $\begin{array}{l}\text { Yes } \\
\text { No } \\
\text { No } \\
\text { No }\end{array}$ & + & $\begin{array}{r}573 \\
104 \\
58 \\
65\end{array}$ & $\begin{array}{l}\text { Abn } \\
\text { Abn } \\
\text { Abn } \\
\text { Abn }\end{array}$ & $\begin{array}{l}\text { Overt } \\
\text { Subclinical } \\
\text { Subclinical } \\
\text { Subclinical }\end{array}$ \\
\hline CMI & $\begin{array}{l}\text { Ib (pr.) } \\
\text { IIa } \\
\text { IIb }\end{array}$ & $\begin{array}{c}\mathrm{F} \\
\mathrm{M} \\
\mathrm{F}\end{array}$ & $\begin{array}{l}66 \\
38 \\
40\end{array}$ & $\begin{array}{l}\text { Yes } \\
\text { No } \\
\text { No }\end{array}$ & + & $\begin{array}{r}4476 \\
620 \\
13\end{array}$ & $\begin{array}{c}\text { Abn } \\
\text { Abn } \\
N\end{array}$ & $\begin{array}{c}\text { Overt } \\
\text { Subclinical } \\
-\end{array}$ \\
\hline
\end{tabular}

* pr. = propositus.

$\dagger$ Abn = abnormal

$\ddagger N=$ normal.

drome, skin fragility and blisters on the sun exposed skin areas, occasionally hypertrichosis and hyperpigmentation; (ii) increased urinary excretion of porphyrins, particularly highly carboxylated porphyrins, uro and heptacarboxylic porphyrins; (iii) abnormal and characteristic fluorescence pattern of the urinary methyl ester porphyrins on TLC, with strong bands at the uroporphyrin (8-COOH porphyrin) as well as at the 7-carboxyl porphyrin zone.
By applying these criteria we can identify two types of PCT: overt and subclinical. In the overt type, skin lesions are present, excretion of urinary porphyrins is increased and the TLC pattern is characteristic. Patients with subclinical PCT have no cutaneous manifestations, excretion of highly carboxylated porphyrins in urine might be normal or increased but TLC of the methyl esters of that urine shows the typical pattern for PCT.
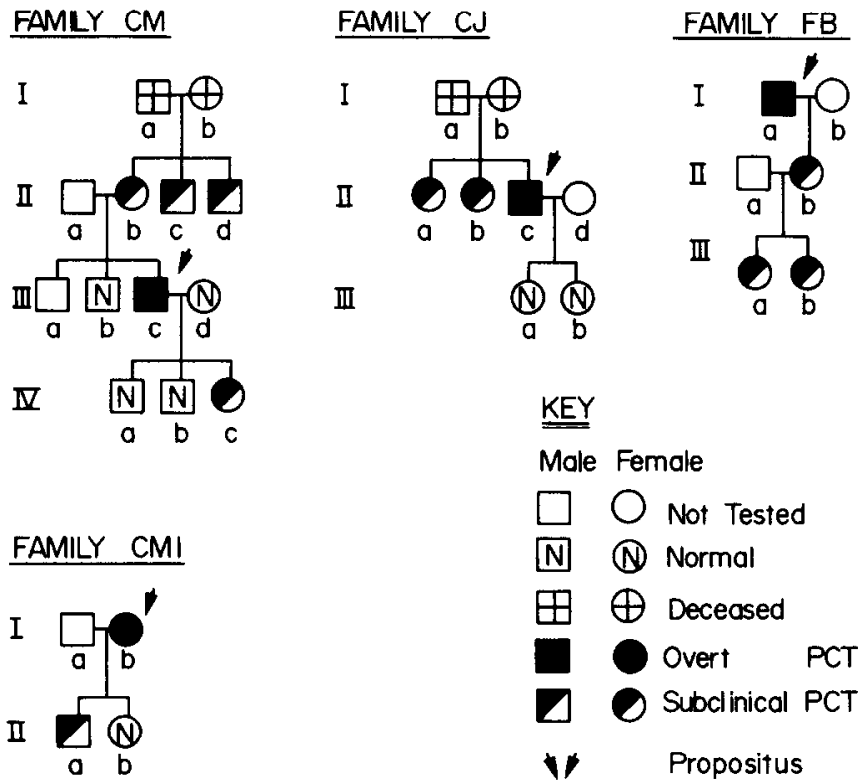

Fig. 1. Pedigree of four families with hereditary PCT. 
In both PCT patients and all their relatives urinary excretion of PBG and ALA was normal. Free erythrocyte protoporphyrin was also within the normal range in all cases. Liver biopsy specimens were only available from some of the PCT patients, which showed intensive red autofluorescence, and contained large amounts of uro and heptacarboxylic porphyrins.

For the purposes of discussion we have divided the 11 families studied in two groups: Group I comprises four families where PCT has been defined as hereditary and Group II includes seven families, where PCT was non-hereditary or acquired.

In Table 1 and Fig. 1, the clinical and laboratory data and the pedigree of families of Group I are shown respectively. If we carefully analyze these findings it is clear that among the 21 members examined, four were the patients (CM IIIc, CJ IIc, FB Ia and CMI Ia) having overt PCT, blistering photo-enhanced dermatosis was present, porphyrin fluorescence was intense in liver biopsy smears, porphyrinuria was high and the TLC urinary pattern was typically abnormal. Ten other relatives (CM IIb, IIc, IId, and IVc; CJ IIa and IIb; FB IIb, IIla and IIIb; CMI IIa) have never developed any cutaneous symptoms, urinary por- phyrin excretion was normal or increased but in all ten, TLC of porphyrins in urine was characteristic of PCT, showing that they have subclinical disease. The remaining seven members studied were completely normal.

These four families are therefore an example of hereditary PCT in which ten individuals not having any cutaneous manifestations and some of them having normal urinary excretion, could be diagnosed as subclinical cases, because the TLC pattern of porphyrins in urine was characteristic of PCT.

In Table 2 the clinical and laboratory data of Group II are shown. Figure 2 illustrates the pedigree of seven families in which PCT was Non-hereditary. From these results, among the 32 members studied, it is clear that in the seven overt PCT patients (TM Ia, LN Ia, TJ Ia, PO Ia, PJ Ia, MRJ Ib and MF Ila) the disorder was acquired because cutaneous manifestations, porphyrinuria and characteristic TLC urinary pattern were only present in the propositus; none of the relatives have ever developed any clinical symptom, and both their urinary porphyrin excretion and TLC pattern were normal.

Therefore, by using clinical data and quantitation

Table 2. Clinical and laboratory data of seven families with non hereditary porphyria cutanea tarda

\begin{tabular}{|c|c|c|c|c|c|c|c|c|}
\hline Family & Case & Sex & $\begin{array}{c}\text { Age } \\
\text { (years) }\end{array}$ & $\begin{array}{l}\text { Clinical } \\
\text { syndrome }\end{array}$ & $\begin{array}{l}\text { Liver } \\
\text { biopsy }\end{array}$ & $\begin{array}{l}\text { Urine } \\
\text { Porphyrins } \\
(\mathrm{g} / 24 \mathrm{hr})\end{array}$ & TLC & $\begin{array}{l}\text { Type of } \\
\text { PCT }\end{array}$ \\
\hline TM & $\begin{array}{l}\text { Ia (pr.) } \\
\text { IIa } \\
\text { IIb } \\
\text { IIc }\end{array}$ & $\begin{array}{l}\mathrm{M} \\
\mathrm{M} \\
\mathrm{F} \\
\mathrm{F}\end{array}$ & $\begin{array}{l}54 \\
16 \\
18 \\
19\end{array}$ & $\begin{array}{l}\text { Yes } \\
\text { No } \\
\text { No } \\
\text { No }\end{array}$ & + & $\begin{array}{r}3197 \\
19 \\
20 \\
10\end{array}$ & $\begin{array}{l}\text { Abn } \dagger \\
\mathrm{N} \ddagger \\
\mathrm{N} \\
\mathrm{N}\end{array}$ & $\begin{array}{c}\text { Overt } \\
- \\
-\end{array}$ \\
\hline LN & $\begin{array}{l}\text { Ia (pr.) } \\
\text { IIa } \\
\text { IIb } \\
\text { IIc } \\
\text { IId }\end{array}$ & $\begin{array}{l}\mathrm{M} \\
\mathbf{M} \\
\mathrm{F} \\
\mathrm{F} \\
\mathrm{F}\end{array}$ & $\begin{array}{l}57 \\
26 \\
28 \\
30 \\
37\end{array}$ & $\begin{array}{l}\text { Yes } \\
\text { No } \\
\text { No } \\
\text { No } \\
\text { No }\end{array}$ & + & $\begin{array}{r}1243 \\
18 \\
52 \\
.10 \\
6\end{array}$ & $\begin{array}{l}\text { Abn } \\
N \\
N \\
N \\
N\end{array}$ & $\begin{array}{c}\text { Overt } \\
- \\
- \\
-\end{array}$ \\
\hline $\mathrm{TJ}$ & $\begin{array}{l}\text { Ia (pr.) } \\
\text { IIa } \\
\text { IIb } \\
\text { IIc }\end{array}$ & $\begin{array}{l}\mathrm{M} \\
\mathrm{F} \\
\mathrm{F} \\
\mathrm{F}\end{array}$ & $\begin{array}{l}60 \\
17 \\
21 \\
25\end{array}$ & $\begin{array}{l}\text { Yes } \\
\text { No } \\
\text { No } \\
\text { No }\end{array}$ & + & $\begin{array}{r}1538 \\
38 \\
10 \\
12\end{array}$ & $\begin{array}{l}\text { Abn } \\
N \\
N \\
N\end{array}$ & $\begin{array}{c}\text { Overt } \\
- \\
- \\
-\end{array}$ \\
\hline PO & $\begin{array}{l}\text { Ia (pr.) } \\
\text { IIa } \\
\text { IIb } \\
\text { IIc }\end{array}$ & $\begin{array}{l}M \\
F \\
F \\
F\end{array}$ & $\begin{array}{r}32 \\
4 \\
6 \\
8\end{array}$ & $\begin{array}{l}\text { Yes } \\
\text { No } \\
\text { No } \\
\text { No }\end{array}$ & & $\begin{array}{r}4727 \\
32 \\
12 \\
11\end{array}$ & $\begin{array}{l}\text { Abn } \\
N \\
N \\
N\end{array}$ & $\begin{array}{c}\text { Overt } \\
- \\
- \\
-\end{array}$ \\
\hline PJ & $\begin{array}{l}\text { Ia (pr.) } \\
\text { IIa } \\
\text { IIb } \\
\text { IIc } \\
\text { IId } \\
\text { IIe } \\
\text { IIf } \\
\text { IIg }\end{array}$ & $\begin{array}{l}\mathbf{M} \\
\mathbf{M} \\
\mathbf{M} \\
\mathbf{F} \\
\mathbf{F} \\
\mathbf{F} \\
\mathbf{F} \\
\mathbf{F}\end{array}$ & 60 & $\begin{array}{l}\text { Yes } \\
\text { No } \\
\text { No } \\
\text { No } \\
\text { No } \\
\text { No } \\
\text { No } \\
\text { No }\end{array}$ & + & $\begin{array}{r}2032 \\
7 \\
13 \\
10 \\
21 \\
22 \\
20 \\
18\end{array}$ & $\begin{array}{l}\text { Abn } \\
N \\
N \\
N \\
N \\
N \\
N \\
N\end{array}$ & $\begin{array}{c}\text { Overt } \\
- \\
- \\
- \\
- \\
- \\
-\end{array}$ \\
\hline MRJ & $\begin{array}{l}\text { Ib (pr.) } \\
\text { IIa } \\
\text { IIb } \\
\text { IIc }\end{array}$ & $\begin{array}{l}F \\
M \\
M \\
F\end{array}$ & $\begin{array}{l}39 \\
14 \\
20 \\
17\end{array}$ & $\begin{array}{l}\text { Yes } \\
\text { No } \\
\text { No } \\
\text { No }\end{array}$ & & $\begin{array}{r}686 \\
17 \\
10 \\
9\end{array}$ & $\begin{array}{l}\text { Abn } \\
N \\
N \\
N\end{array}$ & $\begin{array}{c}\text { Overt } \\
- \\
- \\
-\end{array}$ \\
\hline $\mathbf{M F}$ & $\begin{array}{l}\text { Ia } \\
\text { IIa (pr.) } \\
\text { IIIa }\end{array}$ & $\begin{array}{l}\mathrm{M} \\
\mathbf{M} \\
\mathbf{M}\end{array}$ & $\begin{array}{r}80 \\
22 \\
1\end{array}$ & $\begin{array}{l}\text { No } \\
\text { Yes } \\
\text { No }\end{array}$ & & $\begin{array}{r}29 \\
7157 \\
10\end{array}$ & $\begin{array}{c}N \\
\text { Abn } \\
N\end{array}$ & Overt \\
\hline
\end{tabular}

* pr. = propositus.

$\dagger$ Abn = abnormal.

$\ddagger N=$ normal. 


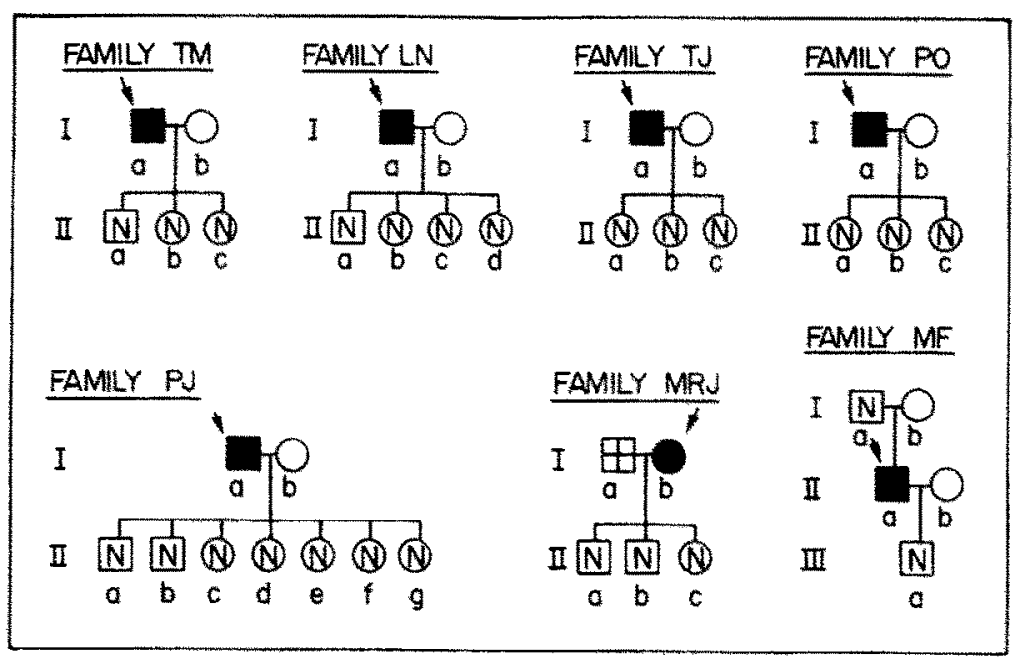

Fig. 2. Pedigree of seven families with non-hereditary PCT.

and TLC of uninary porphyrins we have been able to identify overt and subclinical PCT patients. Among the 11 families studied, in four of these, PCT was a hereditary disease, while in seven other families PCT was a non-hereditary disorder.

These findings are in agreement with the hypothesis on the existance of an acquired and an hereditary form of PCT and stress the importance of carefully performing complete clinical and biochemical investigations of both the patients and all their blood relatives, to be able to determine whether or not there is a pattern of heredity in the famlly and consequently institute proper therapy and prophylaxis.

Acknowledgements-This work was supported by grants from the CONICET, the University of Buenos Aires and the SECVT. A. M. del C. Batlle and E A. Wider de Xifra hold the post of Scientific Researchers in the CONICET We are very grateful to $\mathrm{Dr}$. A. A. Juknat de Geralnik, Dr M. V. Rossetti and Dr V. E. Parera for their valuable help and also to Miss H. Gasparoli, Mr F. Ortega, Mrs I. Jaievsky and $\mathrm{Mr} \mathrm{D}$. Sachetti for their skilful technical assistance.

\section{REFERFNCE}

Batlle A. M. del C., Wider de Xifra E. A. Stella A. M. Rosserti M. V., MaGnin P. H. Moliner A. H, \& LENCzNeR M. I. (1979) Control bioquimico del tratamiento alcalinizante en la Porfinia Cutảnea Tardia. $R$ ev Arg. Derm. in press.

Benedetto A. Y.. James D. O. Kushner J. P. \& Taylor J \$. (1978) Porphyria Cutanea Tarda in three generations of a single family. N. Engl. J. Med. 298, 358-362.

Blekkenhorst R. Pimpstone N. \& Eales L. (1976) Porphyria Cutanea Tarda in South Africa: metabolic basis of disordered haem biosynthesis. In Porphyrins in Human Diseases (Edited by Doss M.) pp. 299-311. Karger, Basel.

Dentin O.. Enerrack L. \& Lundvalx O. (1973) Por phyria Cutanea Tarda: a genetic disease? A biochemical and fuorescence microscopical study in four families. Acta med. Scand. 194, 265-270.

Doss M., Look D., Henning H., Luders C. J., Dolle W \& Strohmeyne G. (1971) Chronische hepatische porphyrien. Z. Klin. Chem. Klin. Biochem. 9, 471-477.
Elder G. H. LeE G. B. \& Tovey J A. (1978) Decreased activity of hepatic uroporphyrinogen decarboxylase in sporadic porphyria cutanea tarda. N. Engl. J. Med. 299, $274-278$.

Felsher B. F. Norris M. E. \& Shih J. C. (1978) Red cell uroporphyrinogen decarboxylase activity in porphyria cutanea tarda and in other forms of porphyria. N. Engl. J. Med. 299, 1095-1098.

Kushiner J. P., Steinmuleer D. P. \& LeE G. R. (1975) The role of iron in the pathogenesis of porphyria cutanea tarda II. Inhibition of uroporphyrinogen decarboxylase. J. cin. Invess. $56,661-667$.

Kushner J. P. Barbutto A. J. \& Lee G. R. (1976) An inherited enzymic defect in porphyria cutanea tarda: $d e-$ creased uroporphyrinogen decarboxylase activity. $J$. clin. Invest. 58. 1089-1097.

MCEW/N R. (1973) The inheritance of porphyria culanea tarda. Med. J. Aust. 2. 398-399.

MAlizerall D. \& Grawick S. (1996) The occurrence and determination of $b$-aminolevulinic acid and porphobilinogen in urine. $J$. biol. Chem $219,435-446$.

Plekor H. \& Thivolet J. (1970) Le role de l'hérédite dans la porphyrie cutanée tardive dite acquise. Ann. Dermat. Syphiligr., Paris 97, 5-14.

Piñol-Aguade J., Hergero C., Almeida J., SMtTh S. G. \& BeLcier R. V. (1975) Thin layer chromatography and counter current analysis in Porphyria. B. J. Dermat. 93. $277-289$

Prato V., Mazza U., Battistini V. \& Massaro L, (1974) Lereditarieta della porfiria cutanea tarda sintomatica. Minerva Med 65, 3599-3613.

Riminoton C. (1971) Quantitative determination of porphobilinogen and porphyrins in urine and porphyrins in feces and erythrocytes. Broadsheet $N 70$. Association of Clinical Pathologist. London.

Topi G. \& D'ALEssandro G. L. (1977) Inheritance of Porphyria Cutanea Tarda. Br. J, Dermat. 97,617-627.

VFrneull. H. de Nordmann Y. Phung N., Grandochamp B., Aitken G., Greluer M. \& NoIre J. (1978) Familial and sporadic porphyria cutanea: two different diseases. int. J. Biochem. 9,927932.

WALDENSTAÖM J. \& HaforR-ARONSEN B. (1967) Different patterns of human porphyria. $B r$. Med. $J .2,272-276$.

Wider de Xifra E. A., Stella A. M., Juknat A. A. Batlle A. M. del C., Magnin P. H. \& Castellanos Pose F. N. M. (1979) Aplicación de la cromatografia en capa delgada en el estudio de la herencia en Porfiria Cutánea Tardita. Rev. Arg. Derm. 60, 226-231. 
WITH T. K. (1975) Clinical use of porphyrin ester chromatography in urine and feces. Dan. Med. Bull. 22, 74-80. WITH T. K. (1976) A simplified system of clinical porphyrin analysis of urine and feces based on TLC. In Porphyrins in Human Disease (Edited by Doss M.) pp. 492-499. Karger, Basel. 